\title{
Modern management directions of investment TNCs' behaviour
}

\author{
Y. A. Shevchenko
}

Department of International Finance, SHEE “Kyiv National Economic University named after Vadym Hetman”, Corresponding author. E-mail: shevchenko-julia@ukr.net

Paper received 05.11.17; Revised 09.11.17; Accepted for publication 15.11.17.

https://doi.org/10.31174/SEND-HS2017-146V24-03

\begin{abstract}
The research is devoted to the main problems concerning modern directions of international investment of TNCs. The modern tendencies of investment activity of TNCs are studied, taking into account the most optimal decisions made by management personnel for a certain period of time. The current specific directions of TNC investment are revealed, which are manifested in connection with the accelerated pace of globalization and the liberalization of international trade rules. The forecasts of future investment behavior of TNCs are given. The article analyzes the state of international investment of TNCs taking into account various factors of the global economic space. The results of the research, which consist in comparison of investment behavior of TNCs in different regions of the world, are determined. The conclusions and recommendations for the construction of a modern strategy for managing the investment behavior of TNCs are developed.

Keywords: environment, investments, investment behaviour, innovations, international investment, TNCs
\end{abstract}

Introduction. Nowadays, TNCs are significant actors in international economic relations. This is due to the fact that international corporations are constantly functioning, developing and trying to calculate every step in their activities. Investments are known to be the main source of economic development for host countries, while TNCs, in turn, diversify their own financial resources to get the most effective outcomes from international investment and with the lowest risks. But TNCs face constant competition at the international level, which prompts them to make optimal investment decisions, taking into account the current conditions and challenges of the global environment.

TNCs are thus trying to transform their own investment behavior to the requirements of international organizations, competitors and the development of modern technologies, that is why the need is to study modern trends deeper and broader in the management of the investment behavior of TNCs.

The analysis of the latest researches and publications. Many foreign and domestic scientists such as L.V.RudenkoSudarieva [5], M.Warren [9] and others involve in research and development of the problems of modern investment directions of TNCs and their behaviour in current economic environment. These researches are based on the theoretical and practical knowledge which is important for the future study and scientific construction. But in result of different changes in the world's economic space, the need of further research of modern investment trends is still remain actual and it is possible to investigate wider investment problems in our economic space and community.

Setting objectives. The purpose of the paper is a thorough study of the modern investment and management decisions, which are made by TNCs according to their investment plan and financial resources, and their environment, which influence on the investment behaviour of multinational corporations, and their implementation of adaptation to modern challenges and opportunities.

Materials and methods. As a result of work, a lot of scientific publications, periodic materials, reports of international organizations, especially UNCTAD, The World Bank Group, Internet resources are used during research. For more thorough study, it were used abstract, comparison and generalization, grouping, graphic methods in this research.

Results and discussions. International investment in our time is carried out in conditions of constant changes and the emergence of new factors that influence the investment behavior of subjects of international economic relations. Such factors are: informatization, robotics, emergence of innovations in any sphere of human life, new technologies and asymmetry of economic development of different countries of the world. Since TNCs are the largest investors in developing countries and the poorest countries, their investments are needed to improve the social and environmental standards of host countries. They need to be competitive in world markets, and therefore the goal of their functioning and competitive advantage is to adhere to the concept of sustainable development.

According to UNCTAD, international investment needs to be made in areas such as infrastructure (roads, ports, railways, power stations, water supply and sewerage networks), food security (agriculture and investment) in order to respect the principles of sustainable development and reduce the external debt of host countries. in the development of rural areas), mitigation and climate change mitigation, health and education [10].

But today, in order to reduce their own risks, TNCs are trying to integrate into joint organizations, partnerships, for example, there is the Sustainable Development Investment Partnership (SDIP). It covers government participants from countries, banks, pension funds and philanthropic organizations, corporations that mobilize their own financial resources to invest in infrastructure development, namely: Cambodia, Canada, Côte d'Ivoire, Denmark, Netherlands, Norway, Sweden, United Kingdom , USA, PensionDanmark, Pensionskassernes Administration (PKA), Standard Chartered, Storebrand, Sumitomo Mitsui Banking Corporation (SMBC), Deutsche Bank, South African Development Bank (DBSA), East Capital, European Bank for Reconstruction and Development (EBRD), European Investment Bank (EIB), Guggenheim Partners LLC, FMO, Senegalese sovereign background Strategic Investments (FONSIS), HSBC, Inter-American Development Bank (IDB), International Development Corporation (IDC), French Development Agency (AFD), African Development Bank (AfDB), Bill \& Melinda Gates Foundation, International Finance Corporation (IFC), Citigroup, Investment Fund for Developing Countries (IFU), Japanese International Agency for Cooperation (JICA), Meridiam Infrastructure, Multilateral Investment Guarantee Agency (MIGA). Over the past five years, the partnership has mobilized \$ 100 billion [7].

The investment was aimed at improving and developing the infrastructure sector in developing countries. In turn, the Investment Partnership for Sustainable Development is supported by the Organization for Economic Cooperation and Development (OECD) and the World Economic Forum 
(WEF). This project was launched at the UN Development Fund for Development in Addis Ababa on July 13-16, 2015. The main interest is also the international investment in "green projects", including in the national strategies of host countries for maintenance and protection of the environment.

According to OECD experts, the largest business activity will be observed in emerging markets and new markets that will appear in the future. But the share of private investment of TNCs will be significant and the management of TNCs will need to focus on new areas of investment, alternative investment. Cooperation and capital accumulation will take place in such areas as: infrastructure, investment in green projects and all that is related to environmental protection, investment in education and educational projects, modern technologies, real estate investments, venture capital, investments in luxury goods etc [4].

Such diversification and changes in the investment behavior of TNCs are primarily due to the turbulence of the financial market, financial crises and, therefore, investment in various facilities will help to reduce political, legal, financial risks and fluctuations in exchange rates, as well as to maintain liquidity of its assets.

It should be noted that according to Pwc's report "Asset Management 2020: A Courageous New World" by 2020, global investment for management purposes will increase to more than $\$ 100$ billion with an annual growth of up to $6 \%$ [4].

Also, the role of alternative investments will grow. For example, the United Nations General Assembly and UN member states adopted the goals of sustainable development that need to be achieved by 2030 . In turn, UNCTAD estimates that by the year 2030 it will be necessary to attract approximately 3.3-4.5 trillion US dollars investments into developing countries in the infrastructure sector (electricity, telecommunications, transport, water and sanitation), as well as in related fields such as: food security, climate change, health and education [6].

Compliance with the concept of sustainable development is key for the next 20-30 years. That is why the management of any TNC is trying to change its own investment and corporate strategy in general. It follows that the implementation of international investment in green infrastructure projects is attractive to investors and the host country definitely establishes the framework and conditions for placement of investments that should be followed in order not to lose its reputation of the corporation and comply with the principle of "social responsibility". This principle forces TNCs to be responsible for their own production, distribution, logistical actions in the host country, while not damaging the health of citizens and the environment.

Investing in green projects, according to the World Investment Report for 2016, shows that it has a small share compared with investment in the extraction of resources in developing countries. As can be seen from figure 1, the largest volume of TNC investment in "green projects" came to the electricity, gas and water sector in 2015 and amounted to 104 billion US dollars [3].

In 2012, the least volumes of investments were sent to both industries: $\$ 32$ billion for electricity, gas and water supply, and 25 billion US dollars for transport. Adoption by the host countries of legal acts, laws and international treaties, the conduct of foreign economic policy taking into account the protection of the environment and the cessation of climate change have increased the volume of investments in the "green projects" in 2015 to 104 billion US dollars in the electricity sector. In turn, investments fell by almost half for the same period in transport from \$ 43 to $\$ 28$ billion. The smallest amount of investments we can see in 2012 is 32 and 25 billion US dollars for electricity and transport, respectively.

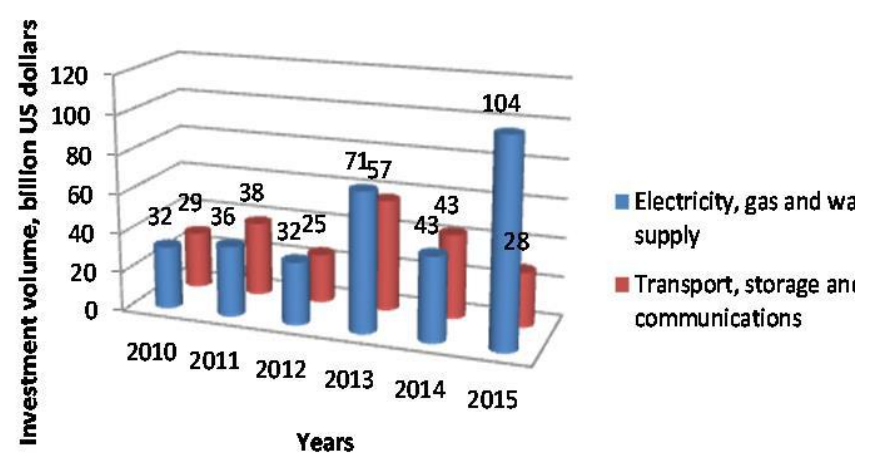

Figure 1. Trends of TNCs' investment volume in green infrastructure projects in 2010-2015, billion US dollars Source: compiled by the author based on [10]

It should be noted that after 2015, the TNC's investment market is reviving, as this period is characterized by postcrisis characteristics and TNCs are transforming investment behavior toward "cautious investments", that is, those with moderate yields and the lowest risks.

Moreover, the infrastructure is attractive and accessible to foreign investors. It is seen as an investment target in developing countries and countries with transition economies. But investors, in this case, choose the "stability-less risk" principle and this industry is more open to financial institutions such as private banks, banks that provide a comprehensive range of services, such as: The New Development Bank or the Asian Infrastructure Investment Bank [1].

It follows that achieving the goals of sustainable development after 2015 in developed countries has become more complicated due to the international community and host countries implementing a mechanism for monitoring the implementation of sustainable development goals. In general, such actions will be implemented with the support of UNCTAD and its bodies in accordance with the agenda and objectives of the World Economic Forum.

The next change in the investment behavior of TNCs is to invest in health and education, as it may say, the social dimension of sustainable development. The first TNCs that began to launch this type of investment were European. The reasons for this transformation were to eliminate the effects of the economic crisis, which affected the host countries, mainly due to the impoverishment of citizens, the increase in chronic diseases and the growing need for quality provision of medical services in connection with the development of technological progress [9].

But for TNCs, developing countries are the most attractive investment countries such as: Malaysia, Singapore, India and Brazil.

In 2017, the Asian region annually invests about $\$ 881$ billion in infrastructure (for 25 countries with sufficient data, accounting for $96 \%$ of the region's population). One of the problems for attracting investments into the region for TNCs is the breakdown of investment in infrastructure, the difference between investment needs and current investment levels, which in 2017 equals $2.4 \%$ of projected GDP for the 5- 
year period from 2016 to 2020 since they began to include climate change mitigation and adaptation

In 2016, Malaysia had investment \$2908 million in the global challenges sector, while in trade was invested $\$ 1,319$ million. These figures were the highest among other sectors. While in telecommunications for 2015-2016 no investments of foreign character. Investors gave money in medical services in 2016 - 1 million US dollars, which is less than 1 million US dollars than in 2015.

This trend is due to the fact that multinational companies in the Malaysian electronics industry have been upgraded from simple to advanced complex processes and products are with high added value. However, this process was neither linear nor homogeneous and depends on several factors, such as public policy, parent corporate identity, auxiliary strategy and the type of product manufactured.

So, according to the Singapore State Statistics Service, in 2016, foreign investment in Singapore amounted to 7217.5 billion US dollars, which is more by 5962 billion US dollars less than 2015 [8].

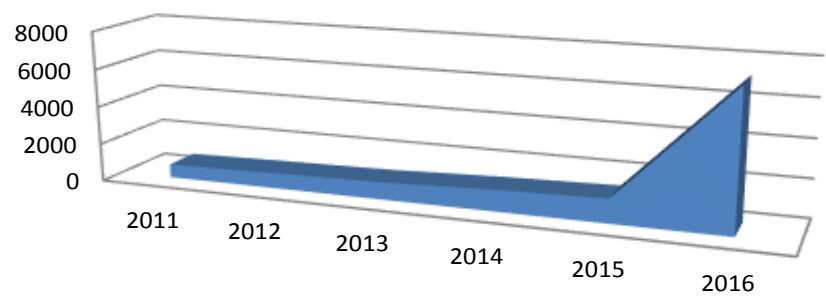

\begin{tabular}{|c|c|c|c|c|c|c|}
\cline { 2 - 6 } \multicolumn{1}{c|}{} & 2011 & 2012 & 2013 & 2014 & 2015 & 2016 \\
\hline $\begin{array}{c}\text { Foreign investments, } \\
\text { billion US dollars }\end{array}$ & 702,6 & 810,1 & 907,1 & 1113,3 & 1255,5 & 7217,5 \\
\hline
\end{tabular}

Figure 2. Trends of TNCs' investment volume in Singapore in 2011-2016, billion US dollars

Source: compiled by the author based on [8]

The lowest volumes of investments were observed in 2011 and 2012 by 702.6 and 810.1 billion US dollars, respectively, as shown in figure 2 .
2014 and 2013 were characterized by more or less stable indicators in the amount of 907.1 and 1113.3 billion US dollars. It should be noted that the main investors with capital origin were in 2015 - the USA, Japan, the Virgin Islands, the Cayman Islands, the Netherlands, the United Kingdom, Bermuda, Luxembourg, Hong Kong and Switzerland.

Singapore is increasingly trying to develop a technology development program that will attract investors from around the world.

Due to increased infrastructure costs, increased tax decentralization and continued fiscal and monetary policy reforms, India's economic forecast has been strengthened. The Government of India is keen to move steadily to minimize structural and political problems, attract more investment and boost economic performance. According to the Economic Outlook for 2016-2017, the gross domestic product of India (GDP) should increase from $6.75 \%$ to $7.5 \%$ in the 2017 2018 fiscal year [2].

According to the Department of Industrial Policy and Assistance of India (DIPP), the total investment in FDI received by India during April 2016 - March 2017 increased by 8\% compared to the previous year to 60,08 billion US dollars, which is a consequence of the Government's efforts in terms of improving business.

Conclusions. Analyzing modern directions of investment behavior of TNCs it is possible to draw the following conclusions:

- the developing countries and the poorest countries are most affected by the lack of investment in health, education, infrastructure and new projects;

- in activities of TNCs for reducing their own risks, TNCs try to integrate into joint organizations, partnerships involving government actors, banks, pension funds and philanthropic organizations, corporations that mobilize their own financial resources to invest in infrastructure development;

- there is a spread of cooperation between TNCs and governments of host countries, especially India, China, Singapore, Malaysia.

\section{REFERENCES}

1. International investment processes in the global economic crisis / O. M. Mozhovyi, L.V. Rudenko-

Sudarieva, U. M. Rudenko, R.V. Krysiuk. Scien-metod. publ. / - M .: Ruta, K .: KNEU, 2015. - P. 34-58.

2. Media Report: Database of Indian Economy. (2017). Retrieved from https://www.ibef.org/economy/domestic-investments.

3. Reports by Malaysian Investment Development Authority. (2017). Retrieved from http://www.mida.gov.my/home/.

4. Report by Pwc. (2017). Retrieved from https://www.pwc.com.

5. Rudenko-Sudarieva L., Krysiuk R Modern factors in the development of international investment / L. Rudenko-Sudarieva., R. Krysiuk // The practical science edition "Independent AUDITOR".2015.- №14 (IV).- P.27-36.

6. The Global Competitiveness Report 2016-2017: World Economic Forum. (2014). Retrieved from https://www.weforum.org/reports/the-global-competitivenessreport-2016-2017-1.

7. The Global Risks Report 2017. (2017). Retrieved from: https://www.weforum.org/reports/the-global-risks-report-2017.

8. Yearbook of Statistics by Department of Statistics of Singapore. (2017). Retrieved from http://www.singstat.gov.sg/statistics/browse-by-theme/investment.

9. Warren M. (2004). A Study of Innovation: Anatomy of the Key Success Factors. Greymatter Strategy\&Innovation. 7-8.

10. World investment report 2016 Investor nationality: policy challenges. (2016). Retrieved from: http://unctad.org/.

\section{Современные направления управления инвестиционным поведением ТНК}

\section{Ю. А. Шевченко}

Аннотация. Исследование посвящено основным проблемам, касающимся направлений международного инвестирования ТНК. Изучены современные тенденции инвестиционной деятельности ТНК, учитывая наиболее оптимальные решения, которые принимает управленческий персонал. Раскрыты современные специфические направления инвестирования ТНК, которые проявляются в связи с ускоренными темпами глобализации и либерализации правил международной торговли. Предоставлено прогнозы относительно будущего инвестиционного поведения ТНК. Проанализировано состояние международного инвестирования ТНК с учетом различных факторов глобального экономического пространства. Определены результаты исследования, заключаются по сравнению инвестиционного поведения ТНК в различных регионах мира. Разработанные выводы и рекомендации по построению современной стратегии управления инвестиционной поведением ТНК.

Ключевые слова: внешняя среда, инвестиции, инвестиционное поведение, международное инвестирование, ТНК. 